\title{
Interpretation of Natural Deconstruction Trough Pandemic Covid-19 Situation Based on "The Garden of Earthly Prosperity in Ground Zero"
}

\author{
Arista Nur Rizki $^{1 *}$, Mudjahirin Thohir ${ }^{2}$ \\ ${ }^{1}$ Diponegoro University, Magister of Literature Department, 50275 Semarang, Indonesia \\ ${ }^{2}$ Diponegoro University, Magister of Literature Department, 50275 Semarang, Indonesia
}

\begin{abstract}
The Garden of Earthly Prosperity in Ground Zero" is a work of art by Isur Suroso. The painting reflects the story of the Sinom song in the text Babad Diponegoro. This fine art tells the story of Prince Diponegoro when he was raised by his great-grandmother in Tegalrejo Village, Yogyakarta. Tegalrejo Village has a simple community pattern. The beautiful natural environments in Tegalrejo Village are silent witnesses to Prince Diponegoro's life. This research aims to describe the concept of visual deconstruction with the COVID-19 pandemic situation. This research uses the deconstruction theory of Jacques Derrida. There are forms of deconstruction meaning through the pandemic situation in this painting. The fine art of "The Garden of Earthly Prosperity in Ground Zero" is divided into three parts. These parts in this fine art can reflect normal life conditions before the coronavirus pandemic appeared and reflect life after the coronavirus pandemic hit the world. The middle part of "The Garden of Earthly Prosperity in Ground Zero" interprets normal conditions. Meanwhile, two other parts describe a pandemic situation.
\end{abstract}

\section{Introduction}

This research originated from a manuscript text entitled Babad Diponegoro. This text is classified as a famous old literary because it tells the story of Prince Diponegoro as a legendary hero from Java. The Babad Diponegoro text is written in Pegon Arabic's script. Interestingly, The Manuscript of Babad Diponegoro was named "Memory of the World" by UNESCO on July 3, 2013.

The author finds other sources of research data, such as the research conducted by Peter Carey in a book entitled Kuasa Ramalan: Pangeran Diponegoro dan Akhir Tatanan Lama di Jawa, 1785-1855 (there are three volumes). In this research, Carey interprets the events contained in the Babad Diponegoro into a narrative accompanied by other supporting data (intertextual method). In addition to the text of the Babad Diponegoro, Carey uses a book entitled "De Java Oorlog" as a text reference. This book contains reports on the results of the Java War from the Dutch (Carey, 2011).

* Corresponding author: aristarizki@students.undip.ac.id 
The Babad Diponegoro text is a historical narrative unit that has a Javanese bound poetry form. According to Susantina (2009), the essence of bound poetry attached to the Babad Diponegoro text can be seen through the rules like song rules (guru lagu), line rules (guru gatra), and syllable rules (guru wilangan). The reflection of the Babad Diponegoro text in the 14th chapter (Sinom song) founded in the form of a painting entitled The Garden of Earthly Prosperity in Ground Zero. This visualisation interprets the story of Prince Diponegoro's teenager through Isur Suroso's creativity. Isur Suroso has succeeded in transforming ancient literary texts into works of art.

The painting is divided into three parts, closely related to the COVID-19 pandemic currently hitting the world. The concept of deconstruction towards the situation of the Tegalrejo community is reflected in this painting. The innovation of this research is in the process of interpreting paintings in a pandemic situation. The painting, which features three parts, can represent the living conditions of people in normal times (before the pandemic hit) and a new 'the new normal era' (when the COVID-19 pandemic hit the world).

This research aims to describe the concept of visual deconstruction with the COVID-19 pandemic situation. The research model was carried out qualitatively by describing the painting. The literature study refers to the Sinom Song Chapter 14th in Babad Dipanegara text and displays the visualization of the painting. The deconstruction process of The Garden of Prosperity in Ground Zero was carried out in accordance with the reflection of the COVID-19 pandemic situation. This research has never been done before. Jacques Derrida's Deconstruction Theory becomes the primary reference in describing the results of the analysis.

\section{Method}

Visualization Visualization is the expression of an idea or feeling using the form of pictures, writing (words and numbers), and another thing [1]. Visualization can be in the form of two-dimensional to three-dimensional images as far as humans can identify through the sense of sight. Painting is one example of a two-dimensional visual image. Deconstruction theory becomes the approach in this research. This theory was developed by a postmodernist literary figure named Jacques Derrida. The deconstruction developed by Derrida is carried out by interpreting a text freely so that it has the potential to present new texts (Ratna:2017). The concept of deconstruction is often associated with the dismantling of meaning that comes from the text. Derrida's Deconstruction thought was strongly influenced by phenomenology, existentialism, and structuralism [2]. Derrida succeeded in developing the interpretation of the text so that it was not merely structural but dynamically through deconstruction. According to Ratna (2017), deconstruction is not a tool for reversing strategy but an activity of reading the meaning of the text in a new way.

Derrida rejects the notion that traditional interpretations are dominated by philosophical logic [4]. Postmodernism groups tend to interpret every narrative in the text beyond the meaning of the author. Without a focus on the author's creativity, the interpretation of the text will get richer. Moreover, the meaning of works of art is always presented abstractly and always raises questions for the interpreter. Derrida used the concept of deconstruction as a tool to fight against structuralism. Deconstructionists are opposed to structuralism that existed before deconstruction theory emerged [6]. By definition, according to Derrida's deconstruction is an alternative way to reject all standard interpretations of meaning.

Deconstruction becomes Derrida's tool to destroy logocentrism [5]. Logocentrism is the assumption of meaning outside the language system, which can be used as a foundation for measuring 'truth'. Derrida's idea through deconstruction is a criticism of previous philosophers such as Freud, Saussure and Levi-Strauss. In essence, deconstruction allows interpretation with the unlimited meaning of a text. The process of interpreting the text 
through deconstruction creates a new text that is not rigid. Deconstruction is closely related to the effort to 'dismantle' the meaning of the text as an effort to enrich the text outside its structure. Derrida finally called this procedure of 'uncovering meaning' with the term 'deconstruction [6].

Deconstruction criticism is not monolithic, including criticism of visual texts such as paintings. The use of deconstruction is interventionist to support different interpretations of a text. This approach is characterized as critical approaches to contradictory, radical, and liberating meaning [7]. The deconstruction theory can be an innovative and productive approach to break the traditional (structural) interpretation perspective. The deconstruction theory approach becomes the guideline for analyzing The Garden of Earthly Prosperity in Ground Zero. The rules for interpreting this painting are described based on the COVID-19 pandemic situation. The deconstruction of The Garden of Earthly Prosperity in Ground Zero produces a meaning of the situation before the COVID-19 pandemic appeared and when the pandemic hit the world ('new normal' condition).

\section{Results and Discussion}

Similar research (using the object of Babad Dipanegara) has also been carried out by Harry Nuriman et al. in the article entitled Gesture Visualization from Babad Diponegoro (UNESCO's MoW) into Digital Character using Motion Capture (published by International Journal of Science and Society). However, that research focuses more on the use of threedimensional graphics technology embedded in the character of Prince Diponegoro. On the other hand, this research utilizes the entire line in the 14th chapter (Sinom Song) of Babad Diponegoro text. The form of this text is bound poetry because it follows the metrum rules of the Sinom song. Metrum rules in the Sinom song are tied to song rules, line rules, and syllables rules in Javanese songs. The song rules are the final rule for the vowel sound at the end of the syllable of each line, the line rules are the rule for the number of lines in each stanza, while the syllable rules are the rule of counting the syllables on each line. The metrum rule in the Sinom song is $8 \mathrm{a}-8 \mathrm{i}-8 \mathrm{a}-8 \mathrm{i}-7 \mathrm{i}-8 \mathrm{u}-7 \mathrm{a}-8 \mathrm{i}-12 \mathrm{a}$ (total of nine lines). The following is an excerpt of the 14th poem of Babad Diponegoro's text, which comes from a book entitled Babad Dipanegara (Manuskrip Bersejarah Memory of The World UNESCO).

Tabel 1. Meaning analysis from the 14th chapter (Sinom Song) of Babad Diponegoro.

\begin{tabular}{|c|c|}
\hline Text & Meaning \\
\hline $\begin{array}{l}\text { Kang buyut tan kenging pisah } \\
\text { Sinambi winulang iki } \\
\text { Langkungkerta Tegalreja } \\
\text { Mapan kabeh tiyang prapti } \\
\text { Samya angungsi tedhi } \\
\text { Ingkang santri ngungsi ngelmu } \\
\text { Langkung rame ngibadah } \\
\text { Punapa dene wong tani } \\
\text { Henengena kawarnaga ing Ngayogya } \\
\\
\text { (Gunawan et al, 2016) }\end{array}$ & $\begin{array}{l}\text { The great-grandmother didn't want to be separated } \\
\text { While continuing to teach him } \\
\text { Peaceful Tegalreja people } \\
\text { Prosperous society } \\
\text { Working hard for life } \\
\text { The students gain knowledge } \\
\text { All diligently worship } \\
\text { The majority of them live farming } \\
\text { A peaceful life in Yogyakarta }\end{array}$ \\
\hline
\end{tabular}




\subsection{Reflection results trough 'The Garden of Earthly Prosperity in Ground Zero' painting}

'The Garden of Earthly Prosperity in Ground Zero' is one of the paintings displayed in 'Pameran Sastra Rupa Babad Diponegoro' in early 2019. This event was organized by Jogja Gallery in collaboration with Patra Padi (the association of the Prince Diponegoro breed). The exhibition displays scenes from Prince Diponegoro's life story based on text sourced from the Babad Dipanegara manuscript. People are presented to enjoy reading ancient literary texts towards understanding visualization in paintings. Society in general also automatically experiences a process of learning literature and history which is not rigid. The aesthetic element through the visual strokes of the painters produced a new alternative, creating text adaptations from the manuscript (Babad Diponegoro) into visual historiography.

The writer's interest relates to the visual illustration of the Sinom song (14th chapter of the Babad Dipanegara text). This visualization was created by an artist named Isur Suroso. The painting described the visualization of Pangeran Diponegoro when his greatgrandmother raised him in Tegalrejo village. The rural atmosphere, which is still beautiful and simple, the people who are active in working (the majority as farmers), the perseverance of the community in worship (religious), and the students who are diligent in studying knowledge are the primary reflections of the atmosphere of life in Tegalrejo village (as written in the Babad Diponegoro manuscript). Some of these factors then shaped the character and character of Prince Diponegoro as an adult.

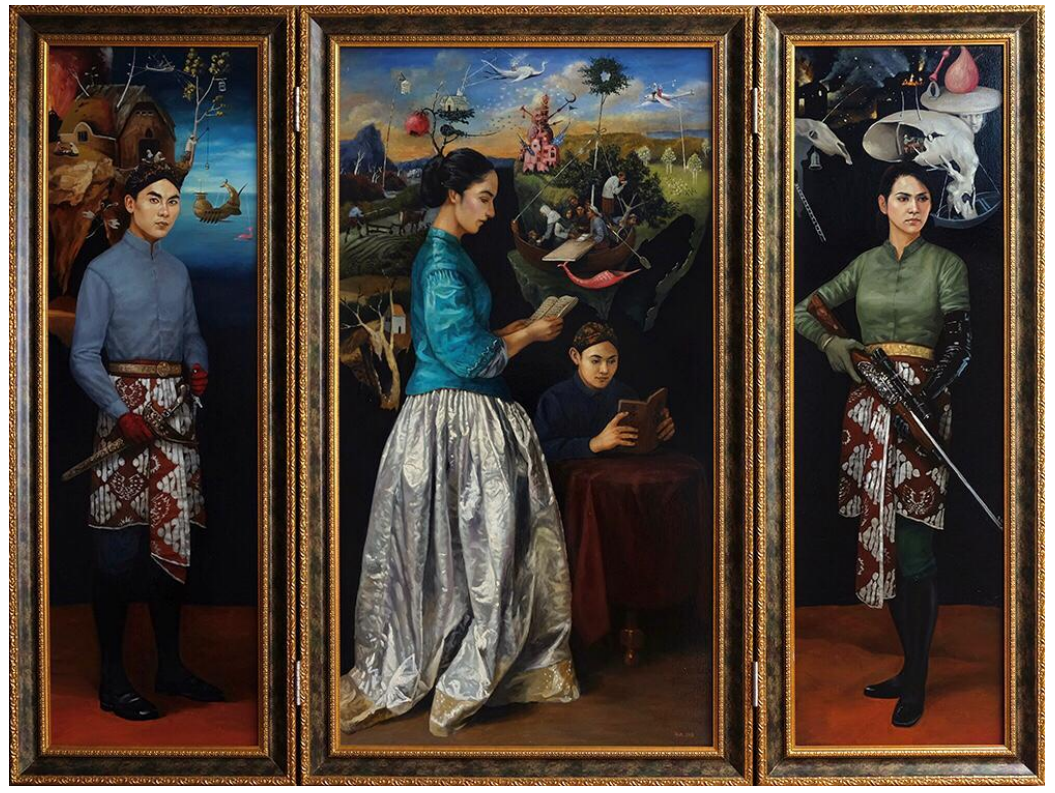

Fig. 1. Illustration of the painting The Garden of Earthly Prosperity in Ground Zero.

Source: web lukisanku.id

(https://www.google.com/amp/s/lukisanku.id/amp/lukis-the-garden-of-earthly-prosperity-in-groundzero-karya-suroso-isur/) accessed on 28 May 2021 at 18:22 p.m. 


\subsection{Deconstruction of the covid-19 pandemic situation based on 'the garden of earthly prosperity in ground zero' painting}

\subsubsection{Normal situation (before the covid-19 pandemic)}

If you look closely, The Garden of Earthly Prosperity in Ground Zero painting, specifically in the middle part, describes the situation of the Tegalrejo people with all their social institutions. The middle part of the painting shows Prince Diponegoro, studying with his grandmother, seen as his teacher. This condition represents the meaning of young people in Tegalrejo village who are active in studying like a 'santri'. Isur Suroso's reflection is in accordance with the quote of the 14th chapter of Babad Diponegoro (on the 6th line). The lyrics read 'ingkang santri ngungsi ngelmu', which means 'all student gains knowledge'. In the background, Isur Suroso as an artist displays the majority of the Tegalrejo people (as farmers). This activity is described by a farmer who is seen as 'herding buffaloes'. The role of farmers represents the majority of the Tegalrejo community's livelihoods. This is consistent with the quotes on lines 5 and 8, which read 'samya angungsi tedhi' (working hard for life) and 'punapa dene wong tani' (the majority of them life farming).

There is also the religiosity of the Tegalrejo community, which is depicted by a small mosque and a group of worshipers. Isur Suroso describes the congregation on the boat. The boat is depicted as carrying worshipers to the mosque. This shows the spirituality of the Tegalrejo people, which is described as being diligent in worship. This concept is consistent with the line 7 lyrics of the 14th line of Babad Dipanegara, which reads 'langkung rame ngibadah' (all diligent worship). If deconstructed, the meanings in the middle painting will appear as normal community activities before the COVID-19 pandemic strikes. The face-toface learning activities at school can still be carried out normally, as illustrated by the figure of Pangeran Diponegoro and his teacher (also great-grandmother), Nyai Ageng Tegalrejo. This is contrary to the situation of teaching and learning activities after the pandemic emerged. The togetherness of Pangeran Diponegoro and Nyai Ageng Tegalrejo is like a teacher and student who are doing face-to-face learning at school. The COVID-19 pandemic causes teaching and learning situations to be carried out with a virtual system.

Meanwhile, the deconstruction of the meaning of farmers who are seen as 'herding buffaloes' describes the normal working activities before the COVID-19 pandemic strikes. As we know, the pandemic has sacrificed the habit of working in the community (working directly in the office). The pandemic has led to a new culture of work activities, namely 'working from home. Apart from these two activities (school and work), worship activities were also ensnared by the pandemic. The deconstruction of a group of worshipers and the mosque icon in the middle painting have suggested a normal state of worship before the pandemic. People can worship quietly in their respective places of worship, such as mosques, churches, or other places of worship in congregation. The COVID-19 pandemic had forced worshipers to pray in their homes to prevent crowds of people. In essence, the deconstruction of the meaning from The Garden of Earthly Prosperity in Ground Zero painting can reflect normal activities in the concept of learning, working, and worship before the COVID-19 pandemic appeared.

\subsection{2 'New normal' situation (when the COVID-19 Pandemic Emerges)}

A deconstruction of the 'new normal' situation in the painting 'The Garden of Earthly Prosperity in Ground Zero' is shown on the right and left parts of the painting. If the centre part of the painting reflects the condition of normal society (before the pandemic), then the meaning of the paintings on the left and right parts is just the opposite. These two paintings will explain the entanglement felt by the public when the COVID-19 pandemic emerged. The 
paintings in these two parts depict the figures of Prince Diponegoro and Nyai Ageng Tegalrejo, which Isur Suroso depicted separately. The separation of the two central figures in the 14th chapter of Babad Dipanegoro is a stark contrast to the centre part of the painting. The two figures are shown differently from the situation in the centre part of the painting.

The figures of Pangeran Diponegoro and Nyai Ageng Tegalrejo, who are described separately (left and right), is a deconstruction concept of 'social distancing' after the COVID19 pandemic strikes. As we know, the transmission of the coronavirus is considered very fast in crowds. Therefore, the concept of 'social distancing' has become a new culture that the community must apply to avoid this dangerous virus. If you look at the painting on the left part, there is an icon in the form of a lake in the background of a young Prince Diponegoro's figure. The results of the deconstruction are also found in the symbol of a lake with abundant water. Water is a sign of the importance of maintaining cleanliness during a pandemic. Water is a means for people to clean themselves to avoid various bacteria, including exposure to the coronavirus. The role of water during a pandemic has become vital with the campaign to wash hands with soap to prevent COVID-19.

Meanwhile, on the right side of the painting is a 'porous bone' icon depicted on the background of Nyi Ageng Tegalrejo (Pangeran Diponegoro's great-grandmother). This icon represents the existence of Nyai Ageng Tegalreja, who is described as an older woman. Broken bones mean the fragility of the community's condition regarding the COVID-19 pandemic situation. The deconstruction meaning of the 'porous bones' in the right part of the painting implies that the danger of the coronavirus is a threat to every human being, especially for the elderly who have a relatively weak immune system. A weak immune system risks making humans easily infected by this deadly virus. In addition, 'porous bones' can also be interpreted as the closeness of humans to the line of death. The COVID-19 pandemic has implicated millions of people around the world as victims; even millions of souls around the world end in death.

\section{Conclusion}

The Garden of Earthly Prosperity in Ground Zero painting by Isur Suroso is a form of transfer from the Babad Diponegoro text. This painting can reconstruct the COVID-19 pandemic situation. The painting, divided into three main parts, reflects the conditions of normal people's lives and 'new normal' life in society. This textual research still has many shortcomings. The COVID-19 pandemic situation caused many limitations in this study. The potential for elaborating the meaning of these two objects can still be done. It is hoped that the analysis of the Babad Dipanegara object and The Garden of Earthly Prosperity in Ground Zero and matters related to the COVID-19 pandemic can be continued in further research.

\section{References}

1. Nuriman, H. et. al. 2021, Gesture Visualization from Babad Diponegoro (UNESCO's MoW) into Digital Character using Motion Capture (Vol. 3, Issue 2), 113-121.

2. Sarup, M. 2003, Poststrukturalisme dan Postmodernisme (Jendela, Yogyakarta)

3. Ritzer, G. 2003, Teori Sosial Postmodern (Kreasi Wacana, Yogyakarta)

4. Kaelan. 2017, Filsafat Bahasa Semiotika dan Hermeneutika. (Paradigma, Yogyakarta)

5. Grenz, S.J. 2001, A Primer on Postmodernism (Yayasan Andi, Yogyakarta) (translated by Wilson Suwanto)

6. Bertens, K. 2001, Filsafat barat kontemporer Perancis (Gramedia Pustaka Utama, Jakarta) 
7. Campbell, N. 2012, Regarding Derrida: The Task of Visual Deconstruction (Vol. 7 No.1), 106.

8. Ratna, N. K. 2009, Estetika Sastra dan Budaya (Pustaka Pelajar, Yogyakarta)

9. Susantina, S. 2009, Tembang Macapat (Panji Pustaka, Yogyakarta)

10. Carey, P. 2011, Kuasa Ramalan : Pangeran Diponegoro dan Akhir Tatanan Lama di Jawa 1786-1855 (Gramedia : Jakarta) 